\title{
Identification of six mRNA sequences of genes related to multixenobiotic resistance (MXR) and biotransformation in Mytilus edulis
}

\author{
Alexander Lüdeking, Angela Köhler* \\ Biologische Anstalt Helgoland in the Foundation of the Alfred Wegener Institute for Polar and Marine Research, \\ Ecophysiology and Ecotoxicology, Am Handelshafen 12, 27570 Bremerhaven, Germany
}

\begin{abstract}
Tissue-specific gene expression of the MXR (multixenobiotic resistance) and biotransformation-related gene homologs for the multidrug resistance protein 1 (Mdr 1), the multidrug resistance protein (Mrp), the major vault protein (Mvp, i.e. the lung resistance protein, Lrp), glutathione S-transferase (Gst pi), heat-shock protein 70 gene (Hsp70), and cytochrome p450 (Cyp4A) was analysed in the blue mussel Mytilus edulis. Additionally, Topoisomerase II (TopoII) and actin were investigated as indicators for mitotic activity and as internal standards. We identified highly conserved regions in the corresponding genes of several other species, and synthesised degenerate olignucleotide primers designed to amplify these regions from $M$. edulis mRNA. Resulting RT-PCR products were cloned into a T-tailed vector and DNA-sequenced. The results were evaluated by computer-based sequence alignment with the known gene sequences of blueprint species. PCR amplified fragments were used as probes for Northern blot hybridisation to identify transcript sizes. Specific oligonucleotide primers were designed from the $M$. edulis sequences for each gene and used for semi-quantitative multiplex RT-PCR to investigate tissue-specific gene expression. We have cloned and DNA-sequenced segments of the M. edulis P-gp, Mvp(Lrp), Gst pi, Hsp70, TopoII and actin genes. Semi-quantitative multiplex RT-PCR rapidly identified characteristic differential geneexpression patterns in a range of mussel tissues, and is therefore a promising tool for comprehensive studies of gene regulation in marine invertebrates in adaptation to various physiological conditions, including responses to natural and anthropogenic stressors.
\end{abstract}

KEY WORDS: Multixenobiotic resistance (MXR) · P-glycoprotein (P-gp) · Major vault protein (MVP) · Heat shock protein 70 (HSP70) - Glutathione S-transferase (GST) · Cytochrome p450 (cytP450) • Multiplex PCR · Mytilus edulis Resale or republication not permitted without written consent of the publisher

\section{INTRODUCTION}

The term 'ecotoxicology' has been coined to describe the relationship between natural toxins, chemical pollutants, the environment into which they are released and the biota in that environment. Because of the diversity of this chemical threat, cells require defence mechanisms of considerable versatility. Although no 2 species of animals defend themselves against the com-

*Corresponding author. E-mail: akoehler@meeresforschung.de plex mixture of toxic substances in exactly the same way, it is remarkable how uniform the adaptation of these strategies is across the living world (Sheehan et al. 1994).

Mussels of the genus Mytilus are among the most common marine molluscs world-wide, and represent an important element in the ecology and economy of coastal waters due to their important role in the food net and in aquafarming. They are sessile filter-feeders and have been shown to be effective concentrators of toxic trace substances, thus reflecting the contamination state of their habitat. Therefore, mussels are now 
widely used as model organisms in toxicological experiments addressing questions of physiology and biochemistry as well as in monitoring programs. However, much less is known of the molecular adaptations that are made at the level of the regulation of gene transcription. We chose the blue mussel $M$. edulis to investigate the regulation of xenobiotic metabolism and elimination at the level of gene expression in order to solve the question to what degree observed changes in protein levels are the result of regulation at the transcriptional or translational levels, and to illuminate the specialisation or co-operation of the known detoxification and elimination mechanisms. Proteins involved in these processes may be divided into 3 main types or 'phases'. Phase I biotransformation enzymes consist mainly of the cytochrome p450 (Cyp450) system, while only the Cyp families 1 to 4 metabolise drugs. Reduction of lipophilic xenobiotics by Cyp450 results either in more polar metabolites, which are easily excreted directly or converted into a chemically more reactive molecule which is a better substrate for Phase II enzymes. In $M$. edulis the CYP4A protein activity is upregulated at polluted sites (Peters et al. 1998), and specific xenobiotic receptor proteins have now been identified in mammals that play a key role in induction of the Cyp4 genes (Waxman 1999). Phase II enzyme activities catalyse the conjugation of the xenobiotic to some endogenous substrates. In M. edulis, glutathione S-transferases (GST), which conjugates glutathione to xenobiotics, play a major role in Phase II reactions. The glutathione S-transferases are a family of enzymes that are mainly cytosolic and catalyse a range of conjugation reactions between glutathione (GSH) and electrophilic substrates. Analysis of mammalian GSTs showed that they also act as intracellular binding proteins, accepting a wide range of endogenous and xenobiotic ligands such as heme, bilirubin, bile acids, steroids and hormones (Litwack et al. 1971).

P-glycoprotein (P-gp), the multidrug resistancerelated protein (Mrp), 2 ATP-driven membrane pumps, and the lung resistance protein (Lrp), which is the major vault protein (Mvp), are members of the Phase III system. Yet, beside their transport ability of conjugated metabolites, these transporters act as a first line of defence by preventing drugs from entry into the cytoplasm or nucleus. They were first identified in cancer cells, where they provide resistance to a broad spectrum of structurally and functionally unrelated drugs, thus causing the phenomenon known as multidrug resistance (Mdr) (Endicott \& Ling 1989). An Mdrlike system called MXR (multixenobiotic resistance) has been identified in marine invertebrates (Kurelec et al. 2000, McFadzen et al. 2000). Beside these biotransformation and elimination systems, upregulated repair mechanisms like the HSP70 molecular chaperone can cause higher tolerance to general stress and xenobiotics (Tedengren et al. 1999) and HSP70 induction is therefore a general marker often used in studies of stress-related effects.

Changes in mitotic activity is a valuable index of the physiological status of individual organisms as it may indicate the absence of proliferating cells caused by xenobiotics, insufficient nutrient supply, as well as reproductive activity. We assayed the expression of Topoisomerase II (TopoII) as a marker of cell proliferation (Heck \& Earnshaw 1986). TopoII is a ubiquitously expressed nuclear protein required for cell division in all organisms investigated so far. The primary role of TopoII is to disentangle (decatenate) intertwined chromosomes during anaphase to allow chromosome segregation to occur prior to cell division. Besides this, it also plays an important role in transcription and, possibly, DNA repair (Withoff et al. 1996).

As these genes had not been sequenced in mussels, we first set out to isolate, clone and sequence complementary DNA fragments for this panel of genes. After characterisation of the clones, based on the sequence information we designed a multiplex-PCR system for fast and sensitive simultaneous analysis of tissuespecific changes in gene expression for potential use as biomarkers in further investigations.

\section{MATERIALS AND METHODS}

Tissue and cell preparation. Blue mussels Mytilus edulis of approximately $5 \mathrm{~cm}$ shell length were collected near the German island of Sylt. Mussels were then cultured at $15^{\circ} \mathrm{C}$ prior to RNA extraction. Reverse transcriptase mMulv and desoxynucleotides were purchased from Peqlab (Erlangen, Germany) and Taq polymerase (RedTaq) from Sigma (Taufkirchen, Germany). Oligo-dT-primers and specific primers for multiplex PCR were obtained from Life Technologies (Karlsruhe, Germany). All other chemicals and supplies were of the purest grade available and were obtained from commercial sources.

Primary cell culture. Cell culture was initiated with enzymatically fragmented mantle tissue by a solution of $400 \mathrm{U}$ collagenase $\mathrm{ml}^{-1}$ in standard saline. Incubation was performed at $4^{\circ} \mathrm{C}$ for $6 \mathrm{~h}$ followed by a $30 \mathrm{~min}$ incubation at $30^{\circ} \mathrm{C}$. Double-strength Leibowitz L15 medium containing $10 \%$ ultroser and antibiotic and antimycotic solution (Life Technologies, Germany), with $\mathrm{pH}$ adjusted to 8.3 and osmolarity at $1100 \mathrm{mOsmol}$ was used as basal medium under atmospheric conditions at $15^{\circ} \mathrm{C}$. Nearly all cells adhered to the culture well within 3 to $5 \mathrm{~d}$. Subsequently, the medium was changed twice a week and the cultures remained stable for up to $8 \mathrm{wk}$. 
Explants. To detect changes in the expression profiles of the genes of interest within 1 individual mussel, different tissues were segregated into small pieces of identical weight. To allow sufficient nutrient supply of cells by diffusion, the mantle tissue was cut into equal blocks of $1 \mathrm{~mm}^{3}$, whereas the gills were dissected into similar-sized fragments of approximately $100 \mathrm{mg}$ in weight. Fragments were rinsed twice in sterile seawater and cultured on 24-well plates. Explants were cultured in autoclaved and filtered seawater at $\mathrm{pH} 8.3$ with HEPES, or in basic medium as described above. Explants showed a homogeneous expression pattern within any one tissue.

Isolation of total RNA and RT-PCR. The foot, posterior adductor muscle, digestive gland, mantle and gills were isolated and total RNA was prepared from all samples immediately after isolation with $1 \mathrm{ml}$ of RNApure reagent (peqlab, Germany), according to the manufacturer's specification. An additional purification step with RNAoptipure was used to remove remaining contamination with polysaccharides. For RT$\mathrm{PCR}$, reverse transcription was performed with $1 \mu \mathrm{g}$ of DNase-treated total RNA with $20 \mathrm{U}$ mMulv reverse transcriptase, 50 pmol oligo-dT primer and $1 \mathrm{mM}$ of dATP, dGTP, dCTP and dTTP (dNTPs), each in a total volume of $30 \mu \mathrm{l}$.

Degenerate primers and PCR. After cDNA synthesis, $10 \mu \mathrm{l}$ of the reaction mixture were used as a template for subsequent PCR. A total volume of $50 \mu \mathrm{l}$ contained $2.5 \mathrm{U}$ of Redtaq and $0.2 \mathrm{mM}$ each of dNTPs. To avoid contamination due to genomic DNA, all samples were treated with DNase I after RNA isolation prior to RT-PCR. After sequence alignment of MXR genes of all vertebrate and invertebrate species, highly conserved regions were identified and degenerate primer pairs were designed to amplify these regions from Mytilus edulis cDNAs.

Sequences for the primers used were: Gst sense: CCI ACI YTI GTI TAY TTY CCI G/antisense: TGY TTI CCR TTI CCR TTI ACI GG, 595 bp; Mvp (Lrp) sense: TTY CCI YTI TAY CCI GGI GAR/antisense: CRT AIA TIC CYT CRT TYT CRT CIA RIG G, 924 bp; Hsp70 sense: ATY AAY GAR CCI ACK GCI GCI GC/antisense: GCY TGI ACI GCW GCI CCR TAI GC, 612 bp; P-gp sense: GTI GGI AGY AGI GGI TGI GG/antisense: TTY TGI ATI GTI GAI AGI CG, 446 bp; actin sense: GTC GGY GAY GAR GCW CAR AGC AA/antisense: GGR CAR CGG AAW CGY TCA TT, 611 bp; Topoisomerase II sense: ATG ATI ATG ACI GAY CAR GAI CAR GAY GG/antisense: CCI GTI CCI ATI CCY TCI GCI CCR TT, 998 bp; Cyp4A sense: GAY ACI TTY ATG TTY GAR GGI CAY G/antisense ATY TTY TGI CCI ATR CAR TCY TGR TCI GG, 436 bp. All primers were used in a concentration of $2 \mu \mathrm{M}$. Ten $\mu$ l of each PCR product was taken for agarose gel electrophoresis (2\% agarose,
1.0 M Tris, 0.9 M boric acid, 0.01 M EDTA). After staining with ethidium bromide, bands of predicted sizes were isolated from the gels and cloned into the sequencing vector Topo 2.1 of Invitrogen (Grohningen, Netherlands). Both strands of at least 3 clones for every cDNA were DNA-sequenced. Sequencing of the successfully cloned insert was performed by the GATCCompany (Konstanz, Germany).

Semi-quantitative multiplex RT-PCR. To perform semi-quantitative multiplex PCR, we measured the amount of isolated total RNA by UV-spectroscopy at $260 \mathrm{~nm}$ and also by non-denaturing gel electrophoresis by comparison with a molecular weight marker. Subsequently, the concentration was adjusted to $1 \mu \mathrm{g} \mathrm{ll}^{-1}$ followed by an additional quantification control by gel electrophoresis. PCR samples of $10 \mu \mathrm{l}$ at Cycles 24, 26 and 28 were analysed by gel electrophoresis to make sure that all genes investigated were still in the exponential phase of amplification. Experiments in which a single primer pair was omitted in the primer mix showed that the amplification of the genes investigated in the exponential phase of PCR was not affected by the others.

Amplification was performed for 26 sequential cycles at $95^{\circ} \mathrm{C}$ for $30 \mathrm{~s}, 55^{\circ} \mathrm{C}$ for $60 \mathrm{~s}$ and $72^{\circ} \mathrm{C}$ for $60 \mathrm{~s}$, followed by a final $3 \mathrm{~min}$ extension at $72^{\circ} \mathrm{C}$. Equal aliquots each of PCR reaction were separated on $2 \%$ agarose gel using TBE-buffer and photographed after ethidium bromide staining. Gels were analysed with Digital Science 1D Image Analysis software (Kodak, Rochester, NY). For semi-quantitative multiplex RT$\mathrm{PCR}$, the following primer pairs were used: CytP450 4 sense: CGA CAC TAC AAC CAG TGC TAT ATC/ antisense ATT GTC CTT TGA GAA GCG ATC TGG ATC, $352 \mathrm{bp}$, concentration in the $\mathrm{PCR}=0.1 \mu \mathrm{M}$ of each; P-gp sense: CAG AGG TTC TAT GAC CCA GAT GCA G/antisense GTT CTC ACT CTC AGA GTC TAA TGC AG, $381 \mathrm{bp}$, concentration in the $\mathrm{PCR}=0.1 \mu \mathrm{M}$ of each; Topoisomerase II sense: CTT CTC TGA TAT GGA CAA ACA TAA GAT TCC/antisense GGA CTG TGG GAC AAC AGG ACA ATA C, $664 \mathrm{bp}$, concentration in the PCR $=0.2 \mu \mathrm{M}$ of each; Mvp (Lrp) sense: ACA GGT TGT AAC TCC CTT G/ antisense CTT CAT GAT GAC CTC GAC C, 818 bp, concentration in the PCR $=0.1 \mu \mathrm{M}$ of each; Gst sense: GTT AGA GGC CGA GCT GAA GC/antisense GGC ATA TTC TTG ACG TGG TC C, 545 bp, concentration in the PCR $=0.1 \mu \mathrm{M}$ of each; actin sense: CTG AGA GTA GCA CCA GAG G/antisense TAG CGC CGA TGA TGA CGC C, $429 \mathrm{bp}$, concentration in the PCR = $0.2 \mu \mathrm{M}$ of each; Hsp70 sense: GAC TTG GGT GGT GGA AC/antisense GGC TAC AGC TTC ATC AGG G, $516 \mathrm{bp}$, concentration in the PCR $=0.1 \mu \mathrm{M}$ of each.

Concentrations in the PCR as mentioned above belong to Primer Set B, while concentrations in Primer 
Set A were $0.1 \mu \mathrm{M}$ for all primers. After determination of the tissue-specific expression patterns in gills, mantle, digestive gland and muscle using primer Set A, primer pair concentrations were modified in the subsequent experiments (Primer Set B). Composition of the primer concentrations was adapted to the tissuespecific abundance of expression for every gene under normal conditions in order to achieve an equal amplification of all genes at every given cycle of the PCR. Quantification of band intensities was measured by Digital Science 1D Image analysis software (Kodak, Rochester, NY). We used the overall intensity of the investigated bands as $100 \%$ net intensity.

Induction of P-gp by 2-acetylaminofluorene. Acetylaminofluorene (AAF), a well-known inducer of P-gptransport activity, was used to address the question of whether we isolated the inducible isoform or a steadystate expressed form. Therefore, gill explants were incubated in 24-well tissue-culture plate in the presence and absence of $2.5 \mathrm{ng} \mathrm{ml}^{-1} 2$-AAF. To avoid problems arising from individual variability, explants were dissected from the same individual mussel for induced and control experiments. Time of induction was $24 \mathrm{~h}$ in standard saline.

Northern blot and transcript-size determination. For Northern blot analysis, $20 \mu \mathrm{g}$ of total RNA obtained from different mussel tissues was separated by electrophoresis on a $0.8 \%$ agarose-formaldehyde gel in MOPS (3-[N-morpholino] propanesulphonic acid) buffer at $60 \mathrm{~V}$ and $50 \mathrm{~mA}$ for $2 \mathrm{~h}$. RNA was then transferred to a positively charged nylon membrane by capillary blotting for $4 \mathrm{~h}$ in $5 \times$ saline-sodium citrate (SSC). RNA was baked on to the blot at $120^{\circ} \mathrm{C}$ for $30 \mathrm{~min}$. After prehybridisation, hybridisation was performed using heatdenatured digoxigenin-labelled PCR products (DIG labelling Kit Roche, Mannheim, Germany) at $42^{\circ} \mathrm{C}$ for $16 \mathrm{~h}$. The hybridisation buffer contained $5 \times$ SSPE buffer $\left(0.75 \mathrm{M} \mathrm{NaCl}, 0.05 \mathrm{M} \mathrm{NaH}_{2} \mathrm{PO}_{4}, 0.005 \mathrm{M}\right.$ EDTA at $\mathrm{pH} 7.4), 50 \%$ formamide, $5 \times$ Denhardt's reagent and $0.5 \%$ SDS. Detection was carried out following the manufacturer's instructions. RNA I and II markers (Roche, Mannheim, Germany) were used to determine molecular weight.

\section{RESULTS}

\section{Identification of 6 mRNA sequences in Mytilus edulis}

Degenerate oligonucleotides were used to amplify sequences within conserved regions of MXR genes from Mytilus edulis cDNA by RT-PCR. Products of the predicted size were detected for P-glycoprotein (P-gp), lung resistance protein gene (Lrp; named the 'major vault protein gene' $[\mathrm{Mvp}]$ in the following text), topo- isomerase II (TopoII), glutathione S-transferase pi (Gst pi), heat shock protein 70 gene (Hsp70), cytochrome p450 4A (Cyp4A) and actin, while primers for the multidrug resistance related protein (Mrp) amplified non-specific products. After gel extraction all fragments were successfully cloned into the Topo 2.1 sequencing vector. Insert length of the cloned fragments was Mvp: 942 bp; Topoisomerase II: 998 bp; Gst pi: 595 bp; Hsp70: 612 bp; actin: 611 bp; P-gp: $446 \mathrm{bp}$; Cyp4A $441 \mathrm{bp}$. In order to ensure that we had not amplified mRNAs from contaminating algae or parasites (often found in gill and mantle tissue) we used primary cell cultures of mantle cells. In such cultures it was possible to detect parasites by microscopy while contaminating algae were washed away by sequential media changes since they do not attach to the culture wells. RT-PCR was performed on parasiteand algae-free cultures using specific primers (Primer Set B). As all fragments were detectable within the entire expression profile at the cell culture level, we exclude contamination as a factor in our previous RT-PCRs using whole tissue.

DNA-sequencing revealed that the PCR products contained sequences complementary to the appropriate primers and also contained appropriate open reading frames. Computer-based sequence analysis using the FASTA3 Internet service (Version 3.3t07 September 19, 2000) of the European Molecular Biology Laboratories (EMBL) (Pearson \& Lipman 1988) revealed high sequence homologies at the nucleotide level compared with other species (data not shown). Homologies at the protein level range from 44 up to $96 \%$ (summarised in Table 1).

Sequence data was then submitted to GenBank: AF172605 838 bp Mytilus edulis major vault protein (Mvp) mRNA, partial coding sequence (cds); AF227976 678 bp M. edulis Topoisomerase II mRNA, partial cds; AF227977 540 bp M. edulis glutathione Stransferase Gst-pi mRNA, partial cds; AF172607 570 bp M. edulis heat-shock protein HSP70 (Hsp70) mRNA, partial cds; AF172606 575 bp $M$. edulis actin mRNA, partial cds; AF159717 446 bp M. edulis p-glycoprotein mRNA, partial cds.

Northern blots were used to identify each of the transcript sizes from Mytilus edulis tissue. Probes were generated and labelled by PCR using the cloned PCR products for each gene as templates and specific primers. Analysis of the blots indicated single bands (Fig. 1) for all the investigated mRNAs and were consistent with transcript sizes identified for a range of invertebrates and vertebrates (Table 2). The exception was Gst, for which a less intense second band occurred at $1000 \mathrm{bp}$. This less intense band may code for the mu isoform of Gsts which shows a $13 \%$ lower similarity compared to the pi form (e.g to mouse Gsts). Because 
Table 1. Mytilus edulis. Percentage of sequence identity of isolated clones with known gene homologs of other species, revealed by sequence alignment using the FASTA3 Internet service. Database searched with SWALL. Program was Fasta33_t. For abbreviations see text

\begin{tabular}{|c|c|c|c|}
\hline Species & & Protein & Amino acid identity (\%) \\
\hline \multicolumn{4}{|l|}{ Major vault protein } \\
\hline Ictalurus punctatus & (channel catfish) & Mvp & 61.5 \\
\hline Discopyge ommata & (electric ray) & Mvp100 & 61.1 \\
\hline Homo sapiens & (human) & Mvp & 58.4 \\
\hline Rattus norwegicus & (Norway rat) & Mvp & 58.0 \\
\hline Mus musculus & (house mouse) & Mvp & 58.0 \\
\hline Dictyostelium discoideum & (slime mold) & Mvp alpha/beta & $57.9 / 49.2$ \\
\hline Leishmania major & (leihshmania) & Mvp & 31.2 \\
\hline \multicolumn{4}{|l|}{ Heat shock protein 70} \\
\hline Crassostrea gigas & (Pacific oyster) & Hsp70 & 94,8 \\
\hline Caenorhabditis elegans & (nematode) & Hsp70A & 84.7 \\
\hline Mus musculus & (house mouse) & HSC71/HspA2/HspA1 & $93.7 / 89.5 / 89.0$ \\
\hline Danio rerio & (zebrafish) & HSC70 & 92.1 \\
\hline Paralichthys olivaceus & (bastard halibut) & Hsp70 & 91.0 \\
\hline Rattus norwegicus & (Norway rat) & HspA2 & 90.1 \\
\hline Homo sapiens & (human) & HSC71/HspA2/HspA1 & $93.7 / 90.1 / 87.3$ \\
\hline Trichinella britovi & (nematode) & Hsp70 & 88.4 \\
\hline Drosophila melanogaster & (fruit fly) & HSC70 & 87.9 \\
\hline \multicolumn{4}{|l|}{ Glutathione S-transferase pi } \\
\hline Homo sapiens & (human) & Gst pi/ Gst mu & $44.0 / 30.0$ \\
\hline Mus musculus & (house mouse) & Gst pi/ Gst mu & $46.6 / 33.7$ \\
\hline Caenorhabditis elegans & (nematode) & Gst pi & 53.2 \\
\hline Danio rerio & (zebrafish) & Gst pi & 45 \\
\hline Bos taurus & $(\mathrm{cow})$ & Gst pi/GST mu & $47.1 / 33.5$ \\
\hline Escherichia coli & (bacteria) & Gst & 33.3 \\
\hline Fasciola hepatica & (liver fluke) & Gst & 32.3 \\
\hline Dirofilaria immitis & (nematode) & Gst pi & 43.1 \\
\hline Onchocerca volvulus & (nematode) & Gst pi & 43.4 \\
\hline \multicolumn{4}{|l|}{ Topoisomerase II } \\
\hline Homo sapiens & (human) & TopoIIalpha/TopoIIbeta & $73.5 / 72.6$ \\
\hline Mus musculus & (house mouse) & TopoIIalpha/TopoIIbeta & $73.0 / 72.6$ \\
\hline Gallus gallus & (chicken) & TopoIIalpha/TopoIIbeta & $75 / 73.0$ \\
\hline Drosophila melanogaster & (fruit fly) & TopoII & 74.3 \\
\hline Caenorhabditis elegans & (nematode) & TopoII & 69.9 \\
\hline Plasmodium falciparum & (malaria parasite) & TopoII & 55.7 \\
\hline Saccharomyces cerevisiae & (baker's yeast) & TopoII & 51.5 \\
\hline \multicolumn{4}{|l|}{ P-glycoprotein } \\
\hline Homo sapiens & (human) & Mdr1/Mdr3 & 69.2/69.1 \\
\hline Mus musculus & (house mouse) & Mdr1/Mdr2/Mdr3 & 69.1/67.5/69.1 \\
\hline Entamoeba histolytica & (entamoeba) & P-gp1 & 69.8 \\
\hline Drosophila melanogaster & (fruit fly) & Mdr50/49/65 & $67.8 / 67.7 / 65.7$ \\
\hline Gallus gallus & (chicken) & CMdr1 & 66.4 \\
\hline Fundulus heteroclitus & (killifish) & Mdr & 67.8 \\
\hline Solanum tuberosum & (potato) & Mdr & 68.4 \\
\hline Caenorhabditis elegans & (nematode) & Mdr1 & 64.8 \\
\hline Rattus norwegicus & (Norway rat) & Sister of P-gp & bile salt export pump \\
\hline Homo sapiens & (human) & Sister of P-gp & 65.1 bile salt export pump \\
\hline \multicolumn{4}{|l|}{ Actin } \\
\hline Homo sapiens & (human) & Actin beta & 96.3 \\
\hline Mus musculus & (house mouse) & Actin & 96.3 \\
\hline Caenorhabditis elegans & (nematode) & Actin2/Act1/Act4 & $96.7 / 95.8 / 95.8$ \\
\hline Drosophila melanogaster & (fruit fly) & Actin2/Act1 & $96.3 / 96.3$ \\
\hline Rattus norwegicus & (Norway rat) & Actin3 & 95.3 \\
\hline \multicolumn{4}{|l|}{ Cytochrome P450-4A } \\
\hline Mytilus galloprovincialis & (Mediterranean mussel) & Сур4Y & 100 \\
\hline Homo sapiens & (human) & Сур4F11/Сур4F2 & $51.9 / 50.7$ \\
\hline Oryctolagus cunniculus & (rabbit) & Сур4А4 & 47.0 \\
\hline Rattus norwegicus & (Norway rat) & Сур4А2/Сур4А1 & $47.7 / 45.0$ \\
\hline
\end{tabular}




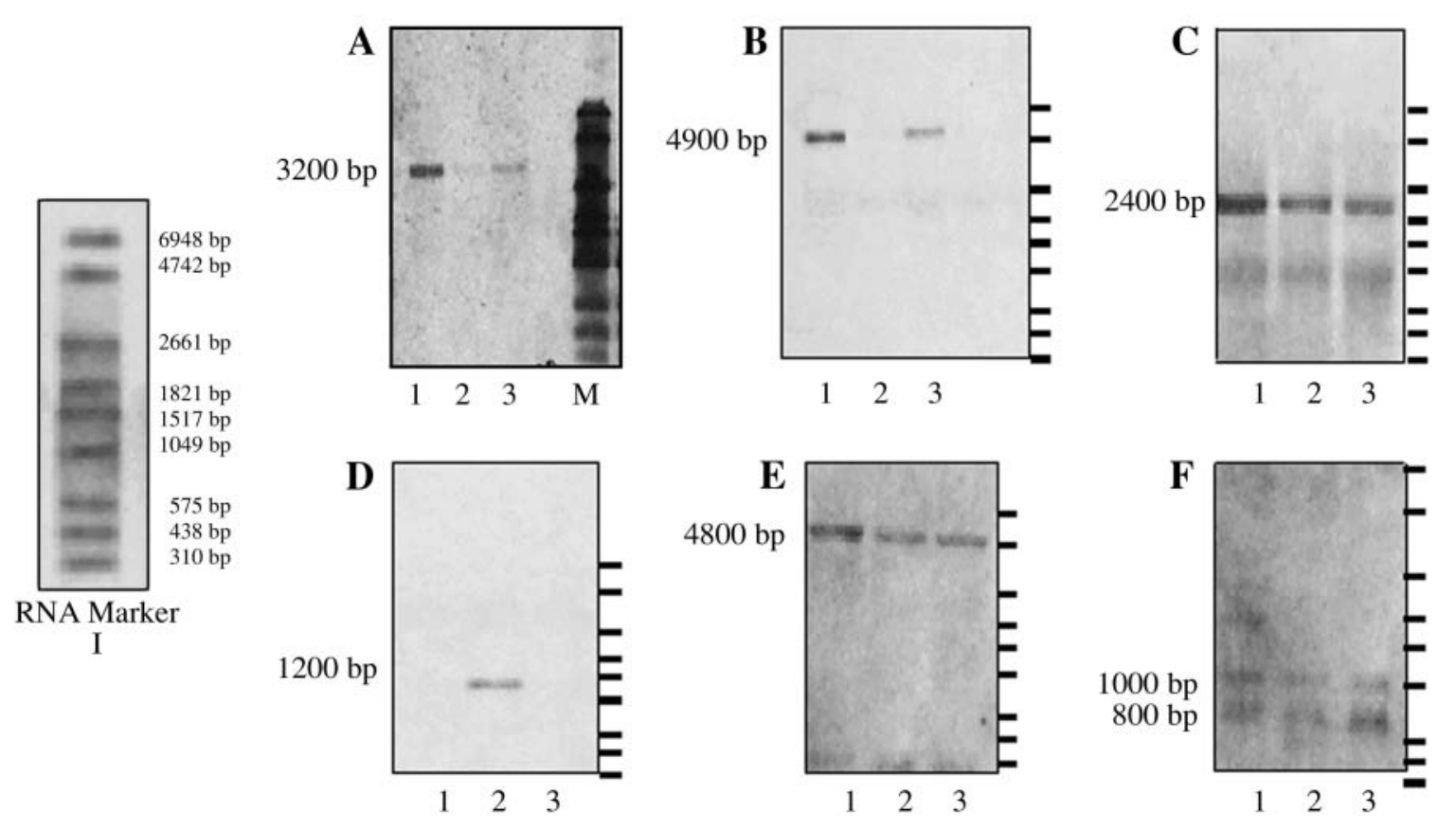

Fig. 1. Mytilus edulis. Northern blot hybridisation of RNA extracted from tissues: $20 \mu \mathrm{g}$ of total RNA were size-separated by gel electrophoresis on a $1 \%$ agarose gel, transferred onto a positive charged nylon membrane, and hybridised with digoxigenin (DIG) labelled PCR probes encoding the cloned regions. Molecular weight marker: RNA Marker I. (A) Mvp(Lrp); (B) P-gp; (C) Hsp70; (D) actin; (E) TopoII; (F) Gst pi; 1: gill; 2: mantle; 3: digestive gland. Bars indicate molecular weight RNA Marker I

of a $100 \%$ sequence identity at the protein and nucleotide level of $M$. edulis and $M$. galloprovincialis for CytP450 4, a Northern blot for transcript size determination was not necessary for the verification of this gene.

\section{Semi-quantitative multiplex RT-PCR and tissue-specific expression}

Based on the sequencing information obtained, a semi-quantitative multiplex RT-PCR was designed to simultaneously assay, in multiple samples, the differential expression of the 7 Mytilus edulis genes of interest (Fig. 2).

Tissue-specific expression was investigated using whole tissues of intact mussels, explanted organs and primary cell culture. Under normal conditions (e.g. of temperature and salinity), explants and primary cultured mantle cells had gene-expression profiles consistent with those of directly dissected mantle tissue. Explants from the same tissue and individual still showed a stable expression profile after dissection and incubation in standard saline for up to $48 \mathrm{~h}$, with the saline changed every $20 \mathrm{~h}$ (Fig. 3). Based on these data we used explants of the same gill, dissected from 1

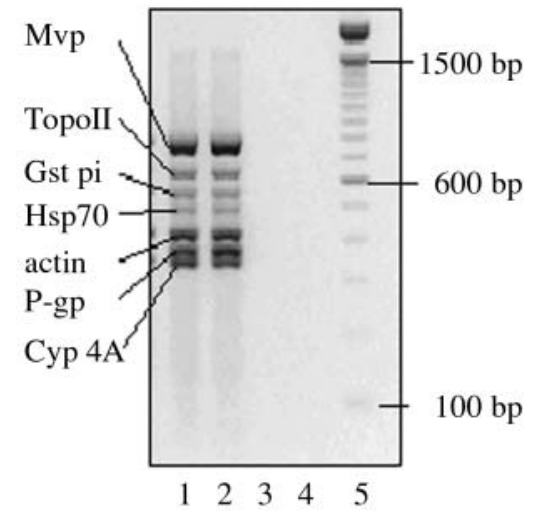

Fig. 2. Mytilus edulis. Semi-quantitative multiplex RT-PCR of P-gp (P-glycoprotein), Mvp (major vault protein), TopoII (Topoisomerase II), Gst pi (glutathion S-transferase, class pi), Hsp70 (heat-shock protein 70), actin and Cyp4A (cytochrome P450 4A). Lanes 1 and 2: mantle tissue; Lane 5: 100 bp marker; Lanes 3 and 4: controls with RNA as template; primer concentration: Set B

Table 2. Mytilus edulis. Transcript size determination by Northern blot hybridisation for Mvp(Lrp), TopoII, Gst pi, Hsp70, actin and P-gp in gill tissue using the molecular weight marker, RNA Marker I

\begin{tabular}{|ccccccc|}
\hline & Mvp & TopoII & Gst pi & Hsp70 & actin & P-gp \\
\hline mRNA size & $3200 \mathrm{bp}$ & $4800 \mathrm{bp}$ & $800 \mathrm{bp}$ & $2400 \mathrm{bp}$ & $1200 \mathrm{bp}$ & $4900 \mathrm{bp}$ \\
\hline
\end{tabular}




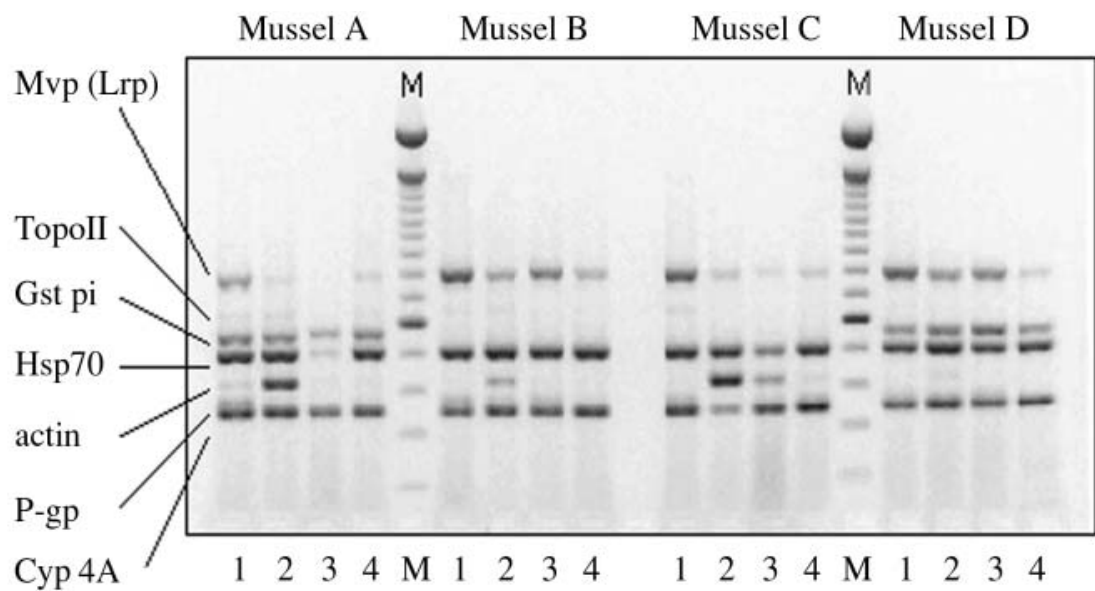

Fig. 3. Mytilus edulis. Tissue-specific expression in 4 individual mussels using semiquantitative multiplex RT-PCR. Lane 1: gill tissue; Lane 2: mantle tissue; Lane 3: digestive gland tissue; Lane 4: foot tissue; M: 100 bp Marker. Primer concentration: Set A

while expression of the other genes investigated was unaffected. Later, during oocyte and sperm maturation, actin expression increased significantly, while gene transcripts of the other genes were no longer detectable by our system using total RNA as the template (Fig. 5). In contrast to mantle tissue, the expression of all genes was unaffected in the other tissues analysed (authors' unpubl. data). Gst pi expression, as shown by investigation of individual gene-expression patterns of whole mussel tissues, was only expressed in some but not all individuals. In those cases in which it was detectable, all tissues were positive for Gst pi and vice versa. These findings were independent

mussel, to provide a unique baseline of expression for induction experiments and controls. The expression profile of primary cell culture was stable for up to $8 \mathrm{wk}$, the maximum culture time used.

Experiments using whole tissues of intact mussels and Primer Set A (Fig. 4) indicated that Mvp mRNA is most abundant in gill and digestive gland tissue, but it was also detectable at a lower level in the mantle and muscle. For P-gp we found a similar expression pattern. A homogeneous expression among all tissues was found for Hsp70 and Cyp4A. For TopoII we found a steady state expression in gills, digestive gland and muscle, while the expression in the mantle is tightly regulated. During the reproductive cycle, expression patterns change dramatically in the mantle tissue, which is the site of gonad development. At first, an induction in Topoisomerase II expression occurred,

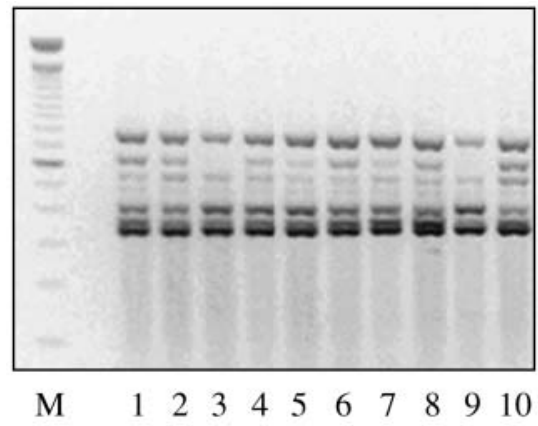

Fig. 4. Mytilus edulis. Gill explants kept under similar conditions for $24 \mathrm{~h}$ in standard saline. Lanes 1, 3, 5, 7 and 9: Explant A at 0, 6, 12, 18 and $24 \mathrm{~h}$; Lanes 2, 4, 6, 8 and 10: Explant B at $0,6,12,18$ and $24 \mathrm{~h}$ of sex and age of the individuals. In summary, differences in the expression of single genes involved in xenobiotic metabolism can now be identified.

\section{Induction of P-gp by 2-acetylaminofluorene}

To determine whether we isolated the stressinducible isoform of P-gp and Hsp70 mRNAs or the constitutively expressed forms, we exposed explants of gill tissue to various kinds of physical or chemical stress followed by RT-PCR. These isoforms share a high homology with their inducible homologs and are, therefore, not distinguishable at the sequence level. We observed an apparent 3-fold increase in steadystate levels of P-gp mRNA when explants were incubated for $24 \mathrm{~h}$ in the presence of $2.5 \mathrm{ng} \mathrm{ml}^{-1} 2-\mathrm{AAF}_{\text {, a }}$

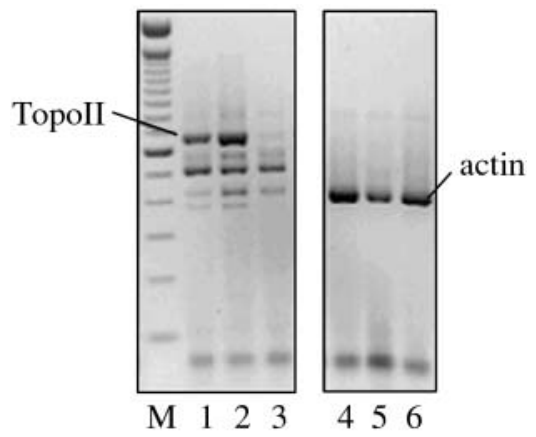

Fig. 5. Mytilus edulis. Changes in the expression pattern of mantle tissue during the reproductive cycle. Lanes 1, 2 and 3: expression pattern before changes in mantle tissue are visible; Lanes 4, 5 and 6: expression pattern of mantle tissue before sperming 

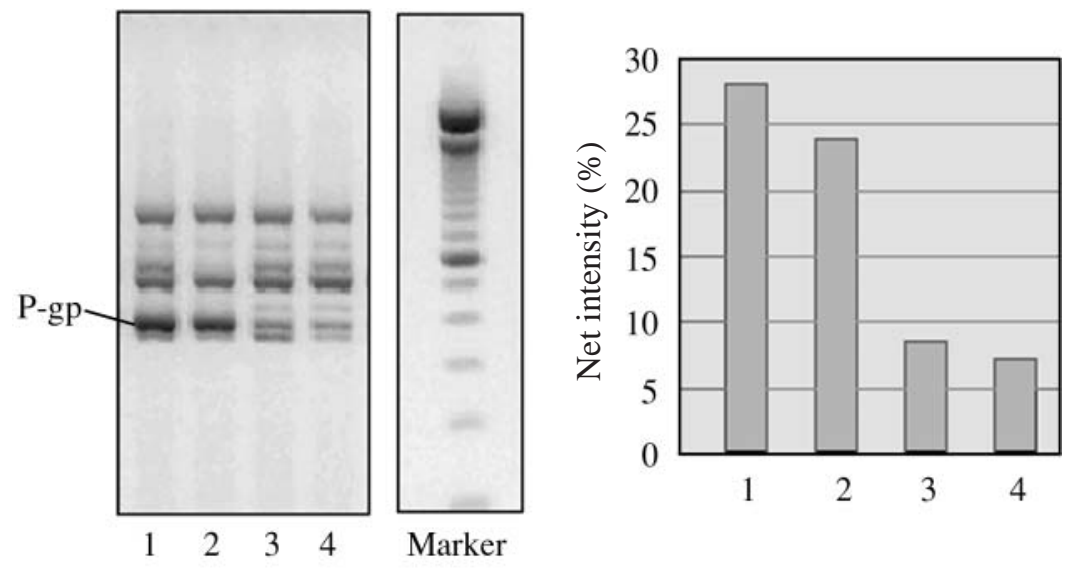

Fig. 6. Mytilus edulis. Induction of P-gp gene expression by 2-AAF as measured by semi-quantitative RT-PCR. Lanes 1 and 2: gill explants exposed to 2-AAF; Lanes 3 and 4: controls without 2-AAF; P-gp band is indicated. Marker $=100 \mathrm{bp}$. Net intensity of the P-gp band in \% of the overall net fluorescence of the amplified bands is shown in right-hand graph which share high-sequence homology, we kept gill explants under heat-stress conditions $\left(30^{\circ} \mathrm{C}\right.$ for $\left.16 \mathrm{~h}\right)$. After this period there was a 2-fold increase in Hsp70 expression compared to gill explants kept at the ambient temperature of $15^{\circ} \mathrm{C}$ (Fig. 7). This result agrees with protein data from other groups using Western blots (Eufemia \& Epel 2000).

\section{DISCUSSION}

Using degenerate primer-based RT-PCR, we have identified previously uncharacterised mRNAs of 5 genes involved in biotransformation and elimination processes of the common mussel Mytilus edulis. The use of degenerate primers to conserved protein domains in PCR is a powerful approach for the identification of new expressed gene sequences from different gene families

well-known inducer of MXR-mediated efflux rates of vinblastine (Fig. 6) (Schrenk et al. 1994). Consequently, we assigned the sequence to the multixenobiotic resistance-conferring isoform of P-gps. The induction is restricted to P-gp: no other gene transcript investigated showed a significant increase after exposure to 2-AAF, underlining the substrate-specific induction.

\section{Hsp70 induction by heat stress}

Because mussel populations are exposed to large temperature fluctuations during the summer, gene regulation following heat stress is of interest. Previous studies have shown upregulation of Hsp70 heat-inducible isoforms at the protein level in response to heat stress (Eufemia \& Epel 2000).

To distinguish between the heat-inducible isoforms of Hsp70 and the steady-state expressed cognates,
(Wilks et al. 1989). The results of our mRNA sequence studies of detoxification enzymes showed the highly homologous structure of the corresponding genes between species. Because sequence identities at the protein level are more informative than at the nucleotide level, we translated the cDNA sequences into amino acid (aa) sequences in silico prior to alignment.

For the prediction of gene family affiliation, homologies at the protein level should achieve at least $40 \%$ identity, and even higher in similarity, compared to known sequences of other species. Aligned sequences should fit, without gaps larger than 8 to 12 aas, across the complete selected sequence range of the proteins with which they are compared. They should be at least 100 aa in length in order to deliver reliable results. Additionally, the mRNA transcript size should be in a similar range to that of other species. All sequences presented in this study fulfil these requirements. There was overall high homology in the aa sequences of all
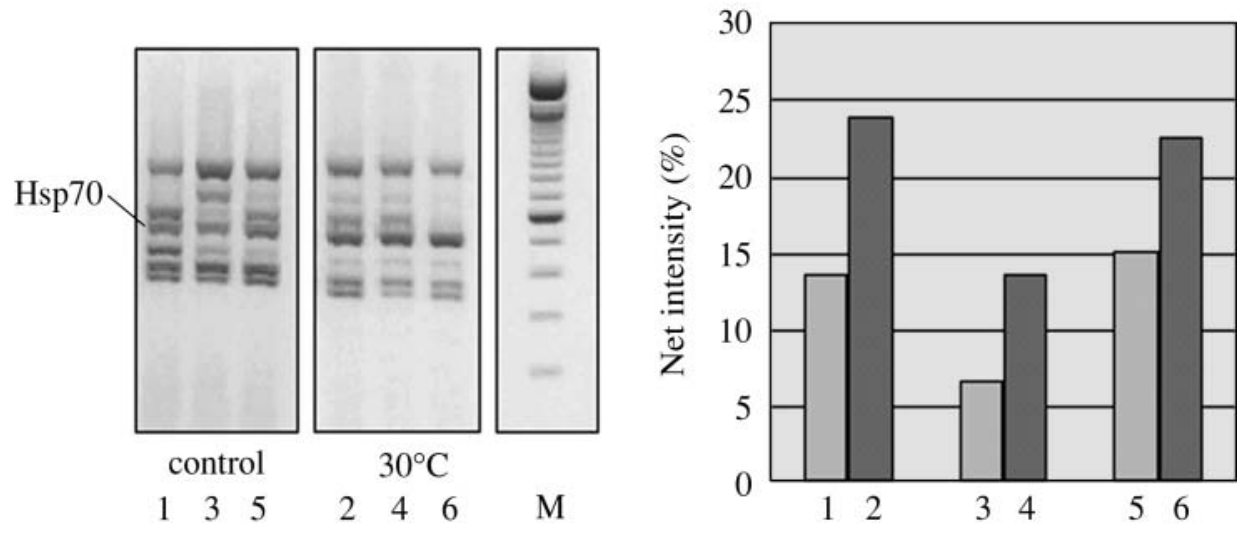

Fig. 7. Mytilus edulis. Induction of Hsp70 gene expression due to exposure to heat stress as measured by semi-quantitative RT-PCR. Gill explants were kept at $30^{\circ} \mathrm{C}$ for $16 \mathrm{~h}$ (Lanes 1, 3 and 5), while control explants were kept at $15^{\circ} \mathrm{C}$ (Lanes 2, 4 and 6). The Hsp70 band is indicated. Marker $=100 \mathrm{bp}$. Net intensity of the Hsp70 band in \% of the overall net fluorescence of the amplified bands is shown in right-hand graph 
cloned cDNA products with the blueprint genes from other species, and they are, therefore, identified as members of the gene families and subfamilies described in the 'Results'.

In particular, homologies of Hsp70 were remarkably high, ranging from 90 to $94 \%$. This underlines the importance and conservation of the chaperone function of Hsp70 among phyla (Tavara et al. 1996). Meanwhile, P-gp, Mvp, TopoII and Gst showed identities of 44 to $75 \%$ within the bilateria.

Homologies among Gst pi class genes are significantly lower than for the other genes investigated, ranging only from 32 to $53 \%$. An explanation for this finding might be their specialisation within an isoform class and their selective substrate specificity in the various phyla due to evolutionary pressure (Whalen \& Boyer 1998). Nevertheless, the homologous nature of stress-gene families and their widespread occurrence among various phyla implies fundamental functions in cellular stress responses.

Our Multiplex RT-PCR system proved to be a fast and sensitive tool for investigating differential expression of these genes. The system can be applied to all kinds of organs and their explants, as well as to primary cultured cells. Therefore, it is an ideal system for comprehensive environmental xenobiotics testing, where problems arise from individual variability in gene expression of intact animals due to the alternative use of explants. Further studies are planned to substitute actin by another marker such as artificial RNA sequences (which are not expressed in mussel) to obtain a better determination of reverse transcription efficiency and amplification differences in PCR. This will also help to circumvent problems with mantle tissue during the reproductive cycle, when quantification of expression levels is impossible using our present system.

Most of the genes investigated in this study, which play a role in cell protection, biotransformation, detoxification and elimination of xenobiotics, are generally transcribed at low levels, the only exception being Gst pi.

Therefore, the transporter genes P-gp and Mvp, whose products prevent drugs from entering the cytoplasm or nucleus, are predominantly expressed in epithelia-rich tissues such as the gills and digestive gland. This again implies their function as the first line of defence against environmental xenobiotics. Expression of Gstp1, the human pi class homolog of M. edulis Gst pi, has been associated with proliferating cells in mature tissues, as a variety of compounds regarded as growth-promoting factors have been positively tested for their abilities to induce the GST promotor (Terrier et al. 1990). Additionally, intracellular levels of this enzyme, which is found in most aerobic eukaryotes and some prokaryotes, may be co-ordinated by a mas- ter gene in response to oxidative stress (Salinas \& Wong 1999). Because cell proliferation in mussels is dependent on their physiological status (e.g. aerobic and anaerobic metabolism), this might explain why expression of Gst pi was detectable in only about $75 \%$ of the mussels investigated. Further experiments on the turnover from aerobic to anaerobic metabolism and feeding behaviour during tidal cycles may answer this question.

In intact animal studies, problems often arise with respect to the variability of individual expression patterns and the effects of external factors such as seasonal changes. Information from laboratory experiments, where effects of individual variability can be reduced to a minimum using explants or primary cell cultures, will give us a better understanding of the complexity of data obtained during field studies. The existence of the MXR mechanism has been confirmed in aquatic organisms by biochemical (Kurelec \& Pivcevic 1989), molecular (immunohistochemical, Western blot) (Kurelec et al. 1992, Minier et al. 1993, Toomey \& Epel 1993, Cornwall \& Toomey 1995, Köhler et al. 1998a,b), physiological (verapamil sensitivity) (Kurelec \& Pivcevic 1991, Galgani et al. 1996, Minier \& Moore 1996) and toxicological (modulation of toxicity) (Waldmann et al. 1993) methods (for review see Bard 2000). Completing the list of approaches, the multiplex RTPCR system enables us to investigate this important mechanism in aquatic invertebrates at the gene regulatory level. Exposure to polluted water increases both MXR activity and protein titer in a concentrationdependent manner (Kurelec et al. 1996, Eufemia \& Epel 1998). Knowledge of the whole set of detoxification and biotransformation genes may considerably improve the characterisation of exposure, a crucial segment in the process of environmental risk assessment.

Based on the sequence data from this study, specific probes for in situ hybridisation and specific antibodies for immunohistochemistry should be synthesised. Additionally it will be possible to screen cDNA banks of different tissues of Mytilus edulis to obtain fulllength sequence information. Dependent on hybridisation stringency, it will be possible to isolate new isoforms of the corresponding gene families, which will allow deeper insights into different gene functions within one and the same gene family. Characterisation of the complete cDNA sequences of this panel of stress-response genes will provide a better understanding of the evolutionary context of gene structure conservation.

Acknowledgements. The authors thank Drs R. van Noorden (AMC, Department of Cell Biology and Histology, University of Amsterdam) and G. Coulton (Department of Biochemistry 
\& Immunology and Department of Cardiological Science, St George's Hospital Medical School, London) for their advice and comments on the manuscript. This study is incorporated into the BEEP project 'Biological Effects of Environmental Pollution in Marine Coastal Ecosystems' (contract EVK3CT2000-00025). The BEEP project is part of the EC IMPACTS cluster. The manuscript is part of a $\mathrm{PhD}$ thesis of Alexander Lüdeking and financed by the Alfred Wegener Institute for Polar and Marine Research.

\section{LITERATURE CITED}

Bard SM (2000) Multixenobiotic resistance as a cellular defence mechanism in aquatic organisms. Aquat Toxicol 48: 375-389

Cornwall R, Toomey BH (1995) Characterization of multixenobiotic/multidrug transport in the gills of the mussel Mytilus californianus and indentification of environmental substrates. Aquat Toxicol 31:277-296

Endicott JA, Ling V (1989) The biochemistry of P-glycoprotein-mediated multidrug resistance. Annu Rev Biochem 58:137-171

Eufemia NA, Epel D (1998) The multixenobiotic defense mechanism is induced by substrates and non-substrates: implications for a general stress response. Mar Environ Res 46:401-405

Eufemia NA, Epel D (2000) Induction of the multixenobiotic defense mechanism (MXR), P-glycoprotein, in the mussel Mytilus californianus as a general cellular response to environmental stresses. Aquat Toxicol 49:89-100

Galgani F, Cornwall R, Toomey BH, Epel D ( 1996) Interaction of environmental xenobiotics with a multixenobiotic defence mechanism in the bay mussel Mytilus galloprovincialis from the coast of California. Environ Toxicol Chem 15:325-331

Heck MM, Earnshaw WC (1986) Topoisomerase II: a specific marker for cell proliferation. J Cell Biol 103:2569-2581

Köhler A, Lauritzen B, Bahns S, George SG, Förlin L, van Noorden CJF (1998a) Clonal adaptation of cancer cells in flatfish liver to environmental contamination by changes in expression of P-gp related MXR, CYP450, GST-A and G6PDH activity. Mar Environ Res 46:191-195

Köhler A, Lauritzen B, Jansen D, Böttcher P, Teguliwa L, Krüner G, Broeg K (1998b) Detection of P-glycoprotein mediated MDR/MXR in Carcinus maenas hepatopancreas by immuno-gold-silver labeling. Mar Environ Res 46:411-414

Kurelec B, Pivcevic B (1989) Distinct glutathione-dependent enzyme activities and a verapamil sensitive binding of xenobiotics in a fresh-water mussel Anodonta cygnea. Biochem Biophys Res Commun 164:934-940

Kurelec B, Pivcevic B (1991) Evidence for a multixenobiotic resistance mechanism in the mussel Mytilus galloprovincialis. Aquat Toxicol 19:291-302

Kurelec B, Krèa S, Pivcevic B, Ugarkoviæ D, Bachmann M, Imsiecke G, Müller WEG (1992) Expression of P-glycoprotein gene in marine sponges: identification and characterisation of the $125-\mathrm{kDa}$ drug-binding glycoprotein. Carcinogenesis 13:69-76

Kurelec B, Krèa S, Luciæ D (1996) Expression of multixenobiotic resistance mechanism in a marine mussel Mytilus galloprovincialis as a biomarker of exposure to polluted environments. Comp Biochem Physiol 113:283-289

Editorial responsibility: Otto Kinne (Editor), Oldendorf/Luhe, Germany
Kurelec B, Smital B, Pivcevic B, Eufemia NA, Epel D (2000) Multixenobiotic resistance, P-glycoprotein, and chemosentizisers. Ecotoxicology 9:307-327

Litwack G, Ketterer B, Arias IM (1971) Ligandin-a hepatic protein which binds steroids, bilirubin, carcinogens and a number of exogenous organic anions. Nature 234:466-667

McFadzen I, Eufemia NA, Heath C, Epel D, Moore M, Lowe D (2000) Multidrug resistance in the embryo and larvae of the mussel Mytilus edulis. Mar Environ Res 50:319-323

Minier C, Moore MN (1996) Rhodamine B accumulation and MXR protein expression in mussel blood cells: effects of exposure to vincristine. Mar Ecol Prog Ser 142:165-173

Minier C, Akcha F, Galgani F (1993) P-glycoprotein expression in Crassostrea gigas and Mytilus edulis in polluted seawater. Comp Biochem Physiol B 106: 1029-1036

Pearson WR, Lipman DJ (1988) Improved tools for biological sequence comparison. Proc Natl Acad Sci USA 85: $2444-2448$

Peters LD, Nasci C, Livingston DR (1998) Variation in levels of cytochrome P4501A, 2B, 2E,3A and 4A-immunopositive proteins in digestive gland of indigenous and transplanted mussel Mytilus galloprovincialis in Venice Lagoon, Italy. Mar Environ Res 46:295-299

Salinas AE, Wong MG (1999) Glutathione S-transferases-a review, Curr Med Chem 6:279-309

Schrenk D, Grant TW, Michalke A, Orzechowski A, Silverman JA, Battula N, Thorgeirsson SS (1994) Metabolic activation of 2-acetylfluorene is required for induction of multidrug resistance gene expression in rat liver cells. Carcinogenesis 15:2541-2546

Sheehan D, McIntosh J, Power A, Fitzpatrick PJ (1994) Drug metabolizing enzymes of mussels as bioindicators of chemical pollution. Biochem Soc Trans 23:419-422

Tavara M, Gabriel T, Kola I, Anderson RL (1996) A hitchhiker's guide to the human Hsp70 family. Cell Stress Chaperones 1(1):23-26

Tedengren M, Olsson B, Reimer O, Brown DC, Bradley BP (1999) Heat pretreatment increases cadmium resistance and HSP 70 levels in Baltic Sea mussels. Aquat Toxicol 48: $1-12$

Terrier P, Townsent AJ, Coindre JM (1990) An immunohistochemical study of pi class glutathione S-transferase expression in normal human tissue. Am J Patho1 37: 845-853

Toomey BH, Epel D (1993) Multixenobiotic resistance in Urechis caupo embryos: protection from environmental toxins. Biol Bull 185:355-364

Waldmann P, Pivcevic B, Muller WEG, Zahn RK, Kurelec B (1993) Increased genotoxicity of acetylaminofluorene by modulators of xenobiotic resistance mechanism: studies with the freshwater clam Corbicula fluminea. Mutat Res 342:113-123

Waxman DJ (1999) P450 Gene induction by structurally diverse xenochemicals: central role of nuclear receptors CAR, PXR, and PPAR. Arch Biochem Biophys 369:11-23

Whalen R, Boyer TD (1998) Human glutathione S-transferases. Sem Liver Dis 18:345-357

Wilks AF, Kurban RR, Hovens CM, Ralph SJ (1989) The application of the polymerase chain reaction to cloning members of the protein tyrosine kinase family. Gene 85(1):67-74

Withoff S, Jong S, de Vries EGE, Mulder NH (1996) Human DNA Topoisomerase II: biochemistry and role in chemotherapy resistance (review). Anticancer Res 16:1867-1880

Submitted: July 9, 2001; Accepted: February 21, 2002

Proofs received from author(s): July 23, 2002 